\title{
Physiological Basis of Improved Performance of Super Rice (Oryza sativa) to Deep Placed Fertilizer with Precision Hill-drilling Machine
}

\author{
M.B. Kargbo ${ }^{1,3}$, Shenggang Pan ${ }^{1,2}$, Zhaowen Mo ${ }^{1,2}$, Zaiman Wang ${ }^{4}$, Xiwen Luo ${ }^{4}$, Hua Tian ${ }^{1,2}$, Md. Faruque Hossain ${ }^{1}$, \\ Umair Ashraf ${ }^{1,2}$ and Xiangru Tang ${ }^{1,2 *}$ \\ ${ }^{1}$ College of Agriculture, South China Agricultural University, Guangzhou, China \\ ${ }^{2}$ Scientific Observing and Experimental Station of Crop Cultivation in South China, Ministry of Agriculture, China \\ ${ }^{3}$ Sierra Leone Agricultural Research Institute, Rokupr Agricultural Research Center, Sierra Leone \\ ${ }^{4}$ Key Laboratory of Key Technology on Agricultural Machine and Equipment, South China Agricultural University, Ministry \\ of Education, Guangzhou 510642, China \\ *For correspondence: tangxr@scau.edu.cn
}

\begin{abstract}
Field experiment on deep placement of fertilizers was carried out using precision hill-drilling machine with the objective of determining super rice growth and photosynthesis characteristics, as well as grain quality in South China. With 'no fertilizer' as control, the four fertilizer combinations were $100 \mathrm{~kg} \mathrm{~N} \mathrm{ha}^{-1}, 100 \mathrm{~kg} \mathrm{~N} \mathrm{ha}^{-1}+60 \mathrm{~kg} \mathrm{SiO}_{2} \mathrm{ha}^{-1}, 125 \mathrm{~kg} \mathrm{~N} \mathrm{ha}^{-1}$, and $125 \mathrm{~kg} \mathrm{~N}^{2}$ $\mathrm{ha}^{-1}+60 \mathrm{~kg} \mathrm{SiO}_{2} \mathrm{ha}^{-1}$. Super rice special fertilizer comprised $12.5 \% \mathrm{~N}, 6.0 \% \mathrm{P}_{2} \mathrm{O}_{5}, 10.0 \% \mathrm{~K}_{2} \mathrm{O}$ and $15 \%$ organic matter. The super rice varieties were Yuejingsimiao 2 (inbred) and Peizataifeng (hybrid) common in South China. The design was splitplot with three replications. Plant height, LAI, SPAD and net photosynthetic rate (NPR) were affected by both variety and fertilizer. Application of $100 \mathrm{~kg} \mathrm{~N}^{-1}$ gave highest GS activity at booting $125 \mathrm{~kg} \mathrm{~N}^{-1}$ resulted in a favorable GS activity from booting to full-heading. SPS activity at booting was highest with $125 \mathrm{~kg} \mathrm{~N} \mathrm{ha}^{-1}+60 \mathrm{~kg} \mathrm{SiO}_{2} \mathrm{ha}^{-1}$. Application of $100 \mathrm{~kg}$ $\mathrm{N}$ ha ${ }^{-1}+60 \mathrm{~kg} \mathrm{SiO}_{2} \mathrm{ha}^{-1}$ to Peizataifeng showed higher GS and SPS activity at booting, and gave the highest head rice rate. While milled rice yield was not, brown rice yield, head rice recovery, rice with chalkiness, and chalky ratio were affected by variety and fertilizer. Treatments were significantly different from each other in polished grain protein and amylose content. Yuejinsimiao 2 fertilized with $125 \mathrm{~kg} \mathrm{~N} \mathrm{ha}^{-1}+60 \mathrm{~kg} \mathrm{SiO}_{2} \mathrm{ha}^{-1}$ recorded the highest protein content and non-fertilized Peizataifeng the least. While Peizataifeng fertilized with $125 \mathrm{~kg} \mathrm{~N}$ ha ${ }^{-1}$ accumulated the highest amount of amylose, Yuejinsimiao 2 fertilized with $100 \mathrm{~kg} \mathrm{ha}^{-1}+60 \mathrm{~kg} \mathrm{SiO}_{2} \mathrm{ha}^{-1}$ had the least. In hybrid Peizataifeng, grain amylose was lower with the silicon-added fertilizers. In inbred Yuejinsimiao 2, grain protein was least when no fertilizer was applied and it increased with addition of silicon and increase in $\mathrm{N} \%$ of fertilizer. We concluded that deep application of rice special fertilizer can improve growth and photosynthesis characteristics, as well as the quality of super hybrid rice. (C) 2016 Friends Science Publishers
\end{abstract}

Keywords: Growth characteristics; Net photosynthetic rate; Enzyme activity; Grain quality; Rice special fertilizer

\section{Introduction}

Rice is a $\mathrm{C}_{3}$ plant with lower dry matter production than $\mathrm{C}_{4}$ cereals like corn and sorghum. Like all other field crops, dry matter production in rice increases as leaf area and light interception increase and then may decrease as the crop approaches physiological maturity. The rate of production is influenced by environmental condition, plant density, cultivar, and management practices (Fageria et al., 1997).

Increased plant height in rice with the increasing levels of $\mathrm{N}$ fertilizer may be attributed to greater supply of nitrogen resulting in increased nitrogen metabolism (Singh and Sharma, 1987). This appeared to increase the length of internodes resulting in higher plant height in the
F3 or F4 fertilizer levels as compared to F0 or lower levels of N fertilizer (Reddy et al., 1987; Milam and Sheppard, 1988).

The role of leaf area index (LAI) and dry matter yields have been studied (Reddy et al., 1982; Rojas et al., 1983; Sredevi and Sreeharan, 1991). It was observed that LAI increased rapidly up to panicle initiation, and rice dry matter yield increased progressively with crop growth in all treatments, and this was due to higher photosynthetic area, better interception of photosynthetically active leaves for longer time as evidenced by significantly higher LAI in these treatments.

There is a strong linear relationship between SPAD values and leaf nitrogen concentration, but this relationship

To cite this paper: Kargbo, M.B., P. Shenggang, M. Zhaowen, W. Zaiman, L. Xiwen, T. Hua, Md. F. Hossain, U. Ashraf and T.X. Ru, 2016. Physiological basis of improved performance of super rice (Oryza sativa) to deep placed fertilizer with precision hill-drilling machine. Int. J. Agric. Biol. 18: 797-804 
varies with crop growth stage and/or variety (Takebe and Yoneyama, 1989; Turner and Jund, 1994). SPAD readings give an indication of chlorophyll content as an index of nitrogen availability.

The role of flag leaf senescence in the availability of nitrogen for grain filling has been investigated (Uauy et al., 2006), pointing out that leaf senescence is not only important for nitrogen mobilization, but for grain yield as well. Leaf proteins, especially photosynthetic proteins of plastids, are extensively degraded during senescence.

Glutamine (Gln) and asparagine (Asn) are the major forms of nitrogen in the xylem sap of rice plants (Fukumorita and Chino, 1982). Glutamine synthetase (GS) acts as a catalyst for assimilating $\mathrm{N}$ taken by the roots of rice plants within the other plant organs (Ireland and Lea, 1999). GS is predominant in the basal or senescing parts. Other important enzymes in rice photosynthesis physiology, and most related to grain filling, are sucrose synthase (SS) and sucrose phosphate synthase (SPS). Sucrose is the primary transport carbohydrate in rice and most other higher plants (Avigad and Dey, 1996; Taiz and Zeiger, 1998) and has been shown to be a major enzyme involved in grain filling (Castleden et al., 2004).

Much emphasis has been directed to the role of nitrogen in improving the yield of rice as well as the quality of the grain. The type of nitrogenous fertilizer may also affect yield and quality of the grain. Yield was greater with calcium ammonium nitrate which proved more efficient than urea when both were used as nitrogen sources (Gately et al., 1988). There is evidence that by applying nitrogen fertilizer on to the panicle initiation stage protein content and, invariably, grain yield of rice could be increased (Patrick and Hoskins, 1974; Matloob et al., 2015). It has shown that nitrogen fertilizer aids protein accumulation in rice grains and restrains amylose accumulation, and gives higher brown rice gel consistency (Hao et al., 2007). In order to improve the overall quality of the rice grain, therefore, much attention has to be placed on nitrogen fertilizer application of the crop.

Deep fertilizer application has been shown to be effective in nitrogen management in flooded lowland rice cultivation; often as a basal application (Fageria et al., 1997). Precision rice hill-drop drilling machine was developed by (Luo et al., 2005; 2007), which showed higher rice yield (Luo et al., 2008; Tang et al., 2009). The technology of precision rice hill-direct-seeding synchronized with fertilizer application can save fertilizer by over $30 \%$ and improve rice yield by $10 \%$ than manual fertilizing (Wang et al., 2010). How this method affects grain quality therefore, becomes worth investigating. Silicon was, however, added to the NPK fertilizer, in this experiment, to counteract the negative effects of the fertilizer $\mathrm{N}$ on rice plants. Therefore, the research focused on the objectives of finding the plant growth and photosynthetic characteristics and the grain quality of super rice hybrids under deep fertilizer application by precision hill-drilling machine - fertilizer placement being one-time (at sowing) synchronized with seeding. This direction was considered necessary in view of resource management efficacy and environmental protection.

\section{Materials and Methods}

\section{Rice Materials}

Two varieties - Yuejinsimiao 2 and Peizataifeng, popular in Guangdong Province, South China, were the rice materials used. Inbred Yuejinsimiao 2, developed by Rice Research Institute, Guangdong Academy of Agricultural Science has a growth period of about 130 days for early season in Guangdong province. Two-line hybrid Peizataifeng, developed by the College of Agriculture, South China Agricultural University (SCAU) has a whole growth period of about 125 days for early season. The two rice varieties have good grain yield and quality traits.

\section{Experimental Site and Conditions}

The field experiment was conducted at the experimental farm of South China Agricultural University, Guangzhou, China (113.18' E, 23.10'N, elevation $18 \mathrm{~m}$ ) in the early season March-July, 2012. Guangzhou has a humid subtropical climate influenced by the Asian monsoon, with a mean annual temperature range of $21-29^{\circ} \mathrm{C}$ (Li et al., 2016; Mo et al., 2016), rainfall of $1,694 \mathrm{~mm}$, and a frost-free period of 345 days. The properties of soil reflective of samples collected from the upper $20 \mathrm{~cm}$ were $19.65 \mathrm{~g} \mathrm{~kg}^{-1}$ organic C, available $\mathrm{N} 106.55 \mathrm{mg} \mathrm{kg}^{-1}$, available P $31.74 \mathrm{mg}$ $\mathrm{kg}^{-1}$ (water as extract), available $\mathrm{K} 189.48 \mathrm{mg} \mathrm{kg}$ (ammonium acetate $\left(1 \mathrm{~mol} \mathrm{~L}^{-1}\right)$ as extract), $\mathrm{SiO}_{2} 52.60 \mathrm{mg}$ $\mathrm{kg}^{-1}$.

\section{Experimental Method}

The land was mechanically ploughed and puddled by oxen. Seeds were hill-drop drilled with precision synchronized with deep fertilizer application by rice hill-drop drilling machine previously developed at the College of Engineering, South China agricultural University. The test varieties, Yuejinsimiao 2 and Peizataifeng, were grown under five fertilizer rates including 'no fertilizer', $100 \mathrm{~kg} \mathrm{~N}$ $\mathrm{ha}^{-1}, 100 \mathrm{~kg} \mathrm{~N} \mathrm{ha}^{-1}+60 \mathrm{~kg} \mathrm{SiO}_{2} \mathrm{ha}^{-1}, 125 \mathrm{~kg} \mathrm{~N} \mathrm{ha}^{-1}, 125 \mathrm{~kg}$ $\mathrm{N} \mathrm{ha}{ }^{-1}+60 \mathrm{~kg} \mathrm{SiO}_{2} \mathrm{ha}^{-1}$. Super rice special fertilizer comprised $12.5 \% \mathrm{~N}, 6.0 \% \mathrm{P}_{2} \mathrm{O}_{5}, 10.0 \% \mathrm{~K}_{2} \mathrm{O}$, and $15 \%$ organic matter. A split plot design with three replications was used and fertilizer rates were in main plots and cultivar treatments in the sub plots. The plot area was $20.0 \mathrm{~m}^{2}$. The trial was carried out in the early season of 2012 (from March $24^{\text {th }}$ to July $19^{\text {th }}$ ) in a field routinely cultivated with rice and vegetables. Plant density was $35 \times 15 \times 14 \mathrm{~cm}$. Alternate wetting and drying irrigation method was adopted and there were no variations in plant protection measures in all the plots. 


\section{Plant Management, Sampling and Measurements}

The fertilizer was applied basal at sowing. Ten cells were established as growing units. These were bonded with mud that was hand-raised and wrapped with polythene sheet to avoid flow of irrigation from one plot to another. This ensured that fertilizers were contained within the plots of application.

At mid-tillering, booting, full heading and maturity, plant samples were collected from all treatments. For this purpose, non-destructive observations on tiller number of 10 hills, at least two boarder rows away, were randomly selected from each plot and recorded and the average number of representative hill was established. Three (3) representative hills, leaving two boarder rows at least, were then randomly uprooted from each plot, washed clean of soil and other surface contaminants and taken to the laboratory for further preparation and measurements. At the laboratory, measurements of plant height and leaf area in order to determine the LAI were made.

SPAD values for each treatment were obtained at full heading. The chlorophyll meter developed by the Soil-Plant Analysis Development (SPAD) unit of Minolta Camera Company (SPAD 502) was used for measuring SPAD. Readings were taken from flag leaves on 20 representative hills per plot located at least two boarder rows further into the plot. Net photosynthetic rate was observed in each treatment at full heading and 15 days after full heading. At each period of measurement the specially designed machine, LI-6400XT Photosynthesis System, was used. Readings were taken from the most healthy, fully expanded uppermost leaf on 20 representative hills per plot (each hill located at least two boarder rows further into the plot).

Plants were harvested manually with sickle at ground level at the yellow-ripe stage from three $1 \mathrm{~m}^{2}$ areas in each plot at least 3 border rows away into the plot. Threshing was mechanically done immediately after harvest and grains were air dried to $12 \%$ moisture. Rough rice samples for quality evaluation were then obtained from each of the aforementioned $1 \mathrm{~m}^{2}$ yield providing samples. After drying, rough rice samples were stored for 3 months at ambient temperature before processing to ensure stable milling yields. The samples, three per treatment, were dehulled and milled in the laboratory with appropriate equipment. Percent hull, brown rice yield, milled rice yield and head rice yield were determined by hand picking, sieving and weighing as necessary. With efficient sampling, the head rice obtained was evaluated for percent rice with chalkiness and chalky ratio of grain by eye evaluation.

The enzymes, GS and SPS were extracted by grinding $0.3 \mathrm{~g}$ leaf samples to a fine powder by liquid nitrogen in a pre-cooled mortar and pestle and then homogenized by Tris$\mathrm{HCl}$ buffer solution ( $\mathrm{pH} 7.6$ ) of $100 \mathrm{mmol} / \mathrm{L} \mathrm{MgCl}_{2}, 1$ $\mathrm{mmol} / \mathrm{L}$ EDTA and $10 \mathrm{mmol} / \mathrm{L}$ 2-mercaptoethanol (for GS); Tris-HCl buffer solution (pH 7.6) of $100 \mathrm{mmol} / \mathrm{L}$ containing
$5 \mathrm{mmol} / \mathrm{L} \mathrm{MgCl}_{2}, 2 \mathrm{mmol} / \mathrm{L}$ EDTA-Na, $2 \%$ ethylene glycol, 2\% BSA, 2\% PVP and $5 \mathrm{mmol} / \mathrm{L}$ DDT (for SPS) at $4^{\circ} \mathrm{C}$. The obtained homogenates were centrifuged at $10000 \mathrm{rpm}$ for GS; and $12000 \mathrm{rpm}$ for SPS for $20 \mathrm{~min}$ at $4^{\circ} \mathrm{C}$. The supernatants were then subjected to measurement of enzyme activities.

GS activity assay and SPS activity assay were determined as specified by China Society of Crop Science (1999).

\section{Statistical Method}

Excel 2003 program was used to prepare all data and the data were analyzed with use of Statistix 9.0 software using ANOVA. Comparisons were made by Duncan's Test at the $5 \%$ level of significance.

\section{Results}

\section{Agronomic and Yield Traits}

At mid-tillering Peizataifeng fertilized with $100 \mathrm{~kg} \mathrm{~N}^{-1}$ produced the tallest plants. At booting, Yuejinsimiao 2 fertilized with $100 \mathrm{~kg} \mathrm{~N} \mathrm{ha}^{-1}+60 \mathrm{~kg} \mathrm{SiO}_{2} \mathrm{ha}^{-1}$ produced the tallest plants, while at maturity Yuejinsimiao 2 fertilized with $125 \mathrm{~kg} \mathrm{~N} \mathrm{ha}^{-1}$ had the tallest plants. At full heading and maturity, except for the non-fertilized treatments, all fertilizer formulas produced taller plants with Yuejinsimiao 2 than with Peizataifeng. The non-fertilized treatments had less plant height at all stages, with cultivar Peizataifeng having the shortest plants at maturity.

\section{Leaf Area Index (LAI) in Super Rice}

At mid-tillering, LAI for Peizataifeng-fertilizer interactions was higher than for Yuejinsimiao-fertilizer interactions, and Peizataifeng fertilized with $100 \mathrm{~kg} \mathrm{~N}^{-1}$ gave the highest LAI. Further, application of $125 \mathrm{~kg} \mathrm{~N} \mathrm{ha}^{-1}+60 \mathrm{~kg} \mathrm{SiO}_{2} \mathrm{ha}^{-1}$ to Peizataifeng produced the greatest LAI at booting and full heading, while application of $125 \mathrm{~kg} \mathrm{~N} \mathrm{ha}^{-1}$ to Peizataifeng gave the greatest LAI at maturity. The nonfertilized treatments of both varieties accounted for the least LAI from booting to maturity. With all treatments, LAI increased markedly from mid-tillering to booting, from booting to full-heading, and then decreased sharply to maturity (Table 2).

\section{SPAD Values in Super Rice}

Application of $125 \mathrm{~kg} \mathrm{~N}^{-1}$ to Peizataifeng produced the highest SPAD value and it was least when no fertilizer was applied to Yuejinsimiao 2. Peizataifeng fertilizer interactions had higher SPAD values than the corresponding Yuejinsimiao 2 - fertilizer treatments, suggesting that variety had a marked influence on SPAD than treatment (Fig. 1). 
Table 1: Interaction effect of super rice varieties and rice special fertilizer formulas on plant height $(\mathrm{cm})$

\begin{tabular}{|c|c|c|c|c|c|}
\hline Hybrids & Treatments & Mid tillering & Booting & Full heading & Maturity \\
\hline \multirow[t]{5}{*}{ Yuejinsimiao 2} & No fertilizer applied & $58.17 \mathrm{de}$ & $93.00 \mathrm{~d}$ & $113.00 \mathrm{e}$ & $117.67 \mathrm{e}$ \\
\hline & $100 \mathrm{~kg} \mathrm{~N} \mathrm{ha}^{-1}$ & $62.67 \mathrm{bc}$ & $99.67 \mathrm{c}$ & $127.87 \mathrm{bc}$ & $128.67 \mathrm{c}$ \\
\hline & $100 \mathrm{~kg} \mathrm{~N} \mathrm{ha}^{-1}+60 \mathrm{~kg} \mathrm{SiO}_{2} \mathrm{ha}^{-1}$ & 60.63 cde & $104.00 \mathrm{abc}$ & $136.67 \mathrm{a}$ & $133.00 \mathrm{~b}$ \\
\hline & $125 \mathrm{~kg} \mathrm{~N} \mathrm{ha}^{-1}$ & $62.00 \mathrm{bcd}$ & $104.67 \mathrm{abc}$ & $128.33 \mathrm{~b}$ & $137.00 \mathrm{a}$ \\
\hline & $125 \mathrm{~kg} \mathrm{~N} \mathrm{ha}^{-1}+60 \mathrm{~kg} \mathrm{SiO}_{2} \mathrm{ha}^{-1}$ & $66.17 \mathrm{ab}$ & $101.00 \mathrm{bc}$ & $129.33 b$ & $134.33 \mathrm{ab}$ \\
\hline \multirow[t]{5}{*}{ Peizataifeng } & No fertilizer applied & $56.60 \mathrm{e}$ & $99.33 \mathrm{c}$ & $115.33 \mathrm{e}$ & $124.00 \mathrm{~d}$ \\
\hline & $100 \mathrm{~kg} \mathrm{~N} \mathrm{ha}^{-1}$ & $68.00 \mathrm{a}$ & $103.33 \mathrm{bc}$ & $122.00 \mathrm{~d}$ & $124.00 \mathrm{~d}$ \\
\hline & $100 \mathrm{~kg} \mathrm{~N} \mathrm{ha}^{-1}+60 \mathrm{~kg} \mathrm{SiO}_{2} \mathrm{ha}^{-1}$ & $62.40 \mathrm{bc}$ & $109.33 \mathrm{a}$ & $126.33 \mathrm{bcd}$ & $128.33 \mathrm{c}$ \\
\hline & $125 \mathrm{~kg} \mathrm{~N} \mathrm{ha}^{-1}$ & $64.67 \mathrm{abc}$ & $106.00 \mathrm{ab}$ & $126.00 \mathrm{bcd}$ & $129.00 \mathrm{c}$ \\
\hline & $125 \mathrm{~kg} \mathrm{~N} \mathrm{ha}^{-1}+60 \mathrm{~kg} \mathrm{SiO}_{2} \mathrm{ha}^{-1}$ & $62.83 \mathrm{bc}$ & $103.33 \mathrm{bc}$ & $123.67 \pm \mathrm{cd}$ & $127.33 \mathrm{c}$ \\
\hline
\end{tabular}

Different letters in the same column mean significantly different at $\mathrm{P}<0.05$ level

Table 2: Interaction effect of super rice variety and rice special fertilizer on Leaf Area Index

\begin{tabular}{|c|c|c|c|c|c|}
\hline Hybrids & Treatments & Mid-tillering & Booting & Full-heading & Maturity \\
\hline \multirow[t]{5}{*}{ Yuejinsimiao 2} & No fertilizer applied & $2.80 \mathrm{e}$ & $10.91 \mathrm{ef}$ & $14.52 \mathrm{~cd}$ & $4.68 \mathrm{~cd}$ \\
\hline & $100 \mathrm{~kg} \mathrm{~N} \mathrm{ha}^{-1}$ & $2.84 \mathrm{e}$ & $17.48 \mathrm{bc}$ & $25.72 \mathrm{ab}$ & $5.39 \mathrm{bcd}$ \\
\hline & $100 \mathrm{~kg} \mathrm{~N} \mathrm{ha}^{-1}+60 \mathrm{~kg} \mathrm{SiO}_{2} \mathrm{ha}^{-1}$ & $3.05 \mathrm{e}$ & 14.30 cde & $19.30 \mathrm{bc}$ & $5.47 \mathrm{bcd}$ \\
\hline & $125 \mathrm{~kg} \mathrm{~N} \mathrm{ha}^{-1}$ & $1.62 \mathrm{f}$ & $17.79 \mathrm{bc}$ & $20.90 \mathrm{bc}$ & $6.50 \mathrm{bcd}$ \\
\hline & $125 \mathrm{~kg} \mathrm{~N} \mathrm{ha}^{-1}+60 \mathrm{~kg} \mathrm{SiO}_{2} \mathrm{ha}^{-1}$ & $3.47 \mathrm{de}$ & $19.84 \mathrm{~b}$ & $22.83 \mathrm{~b}$ & $6.81 \mathrm{bcd}$ \\
\hline \multirow[t]{5}{*}{ Peizataifeng } & No fertilizer applied & $3.97 \mathrm{~cd}$ & $9.20 \mathrm{f}$ & $10.69 \mathrm{~d}$ & $4.24 \mathrm{~d}$ \\
\hline & $100 \mathrm{~kg} \mathrm{~N} \mathrm{ha}^{-1}$ & $6.29 \mathrm{a}$ & $15.23 \mathrm{~cd}$ & $19.17 \mathrm{bc}$ & $7.71 \mathrm{ab}$ \\
\hline & $100 \mathrm{~kg} \mathrm{~N} \mathrm{ha}^{-1}+60 \mathrm{~kg} \mathrm{SiO}_{2} \mathrm{ha}^{-1}$ & $5.15 \mathrm{~b}$ & $13.79 \mathrm{de}$ & $19.61 \mathrm{bc}$ & $6.94 \mathrm{abc}$ \\
\hline & $125 \mathrm{~kg} \mathrm{~N} \mathrm{ha}^{-1}$ & $4.45 \mathrm{bc}$ & $16.71 \mathrm{bcd}$ & $19.91 \mathrm{bc}$ & $9.49 \mathrm{a}$ \\
\hline & $125 \mathrm{~kg} \mathrm{~N} \mathrm{ha}^{-1}+60 \mathrm{~kg} \mathrm{SiO}_{2} \mathrm{ha}^{-1}$ & $4.95 \mathrm{~b}$ & $23.76 \mathrm{a}$ & $29.81 \mathrm{a}$ & $6.02 \mathrm{bcd}$ \\
\hline
\end{tabular}

Different letters in the same column mean significantly different at $\mathrm{P}<0.05$ level

Table 3: Interaction effect of super rice varieties and rice special fertilizer formulas on net photosynthesis rate

\begin{tabular}{llll}
\hline Hybrids & Treatments & Full-heading $(\mathrm{FH})$ & 15 days after full-heading $(\mathrm{DAFH})$ \\
\hline Yuejinsimiao 2 & No fertilizer applied & $18.55 \mathrm{~b}$ & $17.59 \mathrm{c}$ \\
& $100 \mathrm{~kg} \mathrm{Na}^{-1}$ & $15.70 \mathrm{c}$ & $18.00 \mathrm{bc}$ \\
$100 \mathrm{~kg} \mathrm{~N} \mathrm{ha}^{-1}+60 \mathrm{~kg} \mathrm{SiO}_{2} \mathrm{ha}^{-1}$ & $14.49 \mathrm{c}$ & $23.39 \mathrm{a}$ \\
& $125 \mathrm{~kg} \mathrm{ha}^{-1}$ & $14.54 \mathrm{c}$ & $19.98 \mathrm{~b}$ \\
& $125 \mathrm{~kg} \mathrm{ha}^{-1}+60 \mathrm{~kg} \mathrm{SiO}_{2} \mathrm{ha}^{-1}$ & $15.46 \mathrm{c}$ & $22.07 \mathrm{a}$ \\
& $\mathrm{No} \mathrm{fertilizer} \mathrm{applied}^{-1}$ & $24.94 \mathrm{a}$ & $11.35 \mathrm{e}$ \\
& $100 \mathrm{~kg} \mathrm{Na}^{-1}$ & $23.19 \mathrm{a}$ & $14.17 \mathrm{~d}$ \\
$100 \mathrm{~kg} \mathrm{ha}^{-1}+60 \mathrm{~kg} \mathrm{SiO}_{2} \mathrm{ha}^{-1}$ & $19.48 \mathrm{~b}$ & $17.79 \mathrm{bc}$ \\
& $125 \mathrm{~kg} \mathrm{ha}^{-1}$ & $23.29 \mathrm{a}$ & $18.98 \mathrm{bc}$ \\
& $125 \mathrm{~kg} \mathrm{Nha}^{-1}+60 \mathrm{~kg} \mathrm{SiO}_{2} \mathrm{ha}^{-1}$ & $19.73 \mathrm{~b}$ & $22.14 \mathrm{a}$ \\
\hline
\end{tabular}

Different letters in the same column mean significantly different at $\mathrm{P}<0.05$ level

\section{Net Photosynthetic Rate}

At full heading, non-fertilized Peizataifeng had the highest net photosynthetic rate and application of $100 \mathrm{~kg} \mathrm{~N} \mathrm{ha}^{-1}+60$ $\mathrm{kg} \mathrm{SiO}_{2} \mathrm{ha}^{-1}$ to both varieties resulted in least net photosynthetic rate. The Peizataifeng-fertilizer interactions were generally higher in net photosynthesis than their Yuejinsimiao 2 rivals. At 15 days after full-heading (DAFH), $100 \mathrm{~kg} \mathrm{~N} \mathrm{ha}^{-1}+60 \mathrm{~kg} \mathrm{SiO}_{2} \mathrm{ha}^{-1}$ applied to Yuejinsimiao 2 was highest in net photosynthetic rate, and was significantly different from non-fertilized Peizataifeng with the least. Except Peizataifeng fertilized with $125 \mathrm{~kg} \mathrm{~N} \mathrm{ha}^{-1}+60 \mathrm{~kg} \mathrm{SiO}_{2} \mathrm{ha}^{-1}$, the Peizataifeng-fertilizer interactions had low net photosynthetic rates than their Yuejinsimiao 2 counterparts. Of interest, non-fertilized Peizataifeng had the highest net photosynthetic rate at full heading but ended with the least net photosynthetic rate at $15 \mathrm{DAFH}$, while Yuejinsimiao 2 fertilized with $100 \mathrm{~kg} \mathrm{~N} \mathrm{ha}^{-1}+60 \mathrm{~kg}$
$\mathrm{SiO}_{2} \mathrm{ha}^{-1}$ had the least net photosynthetic rate at full heading and gave the highest net photosynthetic rate at 15 DAFH. With the exception of non-fertilized Yuejinsimiao 2 and $125 \mathrm{~kg} \mathrm{~N} \mathrm{ha}^{-1}+60 \mathrm{~kg} \mathrm{SiO}_{2} \mathrm{ha}^{-1}$ applied to Peizataifeng, Peizataifeng showed higher net photosynthetic rate at fullheading and lower net photosynthetic rate at $15 \mathrm{DAFH}$, while the reverse was noticed for Yuejinsimiao 2.

\section{Enzyme Activity}

Glutamate synthase (GS) and sucrose phosphate synthase (SPS) were the enzymes with activity examined at booting for both Yuejinsimiao 2 and Peizataifeng, and at full heading for Peizataifeng. GS activity as influenced by the combined effect of variety and fertilizer (Fig. 2) was highest for Peizataifeng when fertilized with $125 \mathrm{~kg} \mathrm{~N}$ $\mathrm{ha}^{-1}+60 \mathrm{~kg} \mathrm{SiO}_{2} \mathrm{ha}^{-1}$ and was significantly different from other treatments. GS activity at booting was least for both varieties when no fertilizer was applied. 
Super Rice Performance under Deep Placed Fertilizer/Int. J. Agric. Biol., Vol. 18, No. 4, 2016

Table 4: Effect of deep fertilizer application on grain quality in hill-direct seeded hybrid rice

\begin{tabular}{|c|c|c|c|c|c|c|c|c|}
\hline \multicolumn{2}{|c|}{ Hybrids/Treatments } & \multirow{2}{*}{$\begin{array}{l}\begin{array}{l}\text { Brown rice } \\
\text { yield }(\%)\end{array} \\
80.23 \mathrm{~b} \\
\end{array}$} & \multirow{2}{*}{$\begin{array}{l}\begin{array}{l}\text { Milled rice } \\
\text { yield (\%) }\end{array} \\
72.04 \mathrm{a}\end{array}$} & \multirow{2}{*}{$\begin{array}{l}\begin{array}{l}\text { Head rice } \\
\text { recovery }(\%)\end{array} \\
53.21 \mathrm{c}\end{array}$} & \multirow{2}{*}{$\begin{array}{l}\begin{array}{l}\text { Rice with } \\
\text { chalkiness }(\%)\end{array} \\
1.33 \mathrm{e}\end{array}$} & \multirow{2}{*}{$\begin{array}{l}\text { Chalky } \\
\text { ratio } \\
0.67 \text { a }\end{array}$} & \multirow{2}{*}{$\begin{array}{l}\begin{array}{l}\text { Protein } \\
(\%)\end{array} \\
8.00 \mathrm{~h} \\
\end{array}$} & \multirow{2}{*}{$\begin{array}{l}\begin{array}{l}\text { Amylose } \\
(\%)\end{array} \\
21.40 \mathrm{~b}\end{array}$} \\
\hline Yuejinsimiao 2 & No fertilizer applied & & & & & & & \\
\hline & $100 \mathrm{~kg} \mathrm{~N} \mathrm{ha}^{-1}$ & $80.69 \mathrm{~b}$ & $71.81 \mathrm{a}$ & $64.21 \mathrm{ab}$ & $3.00 \mathrm{de}$ & $0.53 \mathrm{bc}$ & $9.37 \mathrm{f}$ & $20.83 \mathrm{bcd}$ \\
\hline & $100 \mathrm{~kg} \mathrm{Nha}^{-1}+60 \mathrm{~kg} \mathrm{SiO}_{2} \mathrm{ha}^{-1}$ & $81.13 \mathrm{ab}$ & $72.36 \mathrm{a}$ & $62.44 \mathrm{~b}$ & $3.00 \mathrm{de}$ & $0.61 \mathrm{abc}$ & $9.90 \mathrm{c}$ & $18.10 \mathrm{e}$ \\
\hline & $125 \mathrm{~kg} \mathrm{~N} \mathrm{ha}^{-1}$ & $80.88 \mathrm{ab}$ & $73.05 \mathrm{a}$ & $62.25 \mathrm{~b}$ & $5.33 \mathrm{de}$ & $0.54 \mathrm{abc}$ & $10.0 \mathrm{~b}$ & $19.40 \mathrm{de}$ \\
\hline & $125 \mathrm{~kg} \mathrm{Nha}^{-1}+60 \mathrm{~kg} \mathrm{SiO}_{2} \mathrm{ha}^{-1}$ & $80.61 \mathrm{~b}$ & $72.85 \mathrm{a}$ & $64.91 \mathrm{ab}$ & $1.67 \mathrm{de}$ & $0.51 \mathrm{~cd}$ & $10.20 \mathrm{a}$ & $20.53 \mathrm{bcd}$ \\
\hline \multirow[t]{5}{*}{ Peizataifeng } & No fertilizer applied & $85.54 \mathrm{a}$ & $70.33 \mathrm{a}$ & $39.30 \mathrm{e}$ & $54.33 \mathrm{a}$ & $0.39 \mathrm{~d}$ & $6.30 \mathrm{j}$ & $23.70 \mathrm{a}$ \\
\hline & $100 \mathrm{~kg} \mathrm{~N} \mathrm{ha}^{-1}$ & $79.89 \mathrm{~b}$ & $71.88 \mathrm{a}$ & $48.81 \mathrm{~d}$ & $26.67 \mathrm{~b}$ & $0.54 \mathrm{abc}$ & $9.57 \mathrm{e}$ & $24.60 \mathrm{a}$ \\
\hline & $100 \mathrm{~kg} \mathrm{~N} \mathrm{ha}^{-1}+60 \mathrm{~kg} \mathrm{SiO}_{2} \mathrm{ha}^{-1}$ & $79.54 \mathrm{~b}$ & $71.66 \mathrm{a}$ & $66.33 \mathrm{a}$ & $6.00 \mathrm{~d}$ & $0.65 \mathrm{ab}$ & $7.60 \mathrm{i}$ & $19.83 \mathrm{~cd}$ \\
\hline & $125 \mathrm{~kg} \mathrm{~N} \mathrm{ha}^{-1}$ & $80.62 \mathrm{~b}$ & $72.56 \mathrm{a}$ & $54.22 \mathrm{c}$ & $30.00 \mathrm{~b}$ & $0.50 \mathrm{~cd}$ & $8.20 \mathrm{~g}$ & $24.87 \mathrm{a}$ \\
\hline & $125 \mathrm{~kg} \mathrm{~N} \mathrm{ha}^{-1}+60 \mathrm{~kg} \mathrm{SiO}_{2} \mathrm{ha}^{-1}$ & $80.00 \mathrm{~b}$ & $71.74 \mathrm{a}$ & $65.63 \mathrm{ab}$ & $15.00 \mathrm{c}$ & $0.54 \mathrm{abc}$ & $9.80 \mathrm{~d}$ & $21.10 \mathrm{bc}$ \\
\hline
\end{tabular}

Different letters in the same column mean significantly different at $\mathrm{P}<0.05$ level

Further, GS activity in Peizataifeng at full-heading as influenced by fertilizer formulas was highest with the application of $100 \mathrm{~kg} \mathrm{~N} \mathrm{ha}^{-1}$ and insignificantly different from the non-fertilized treatment, and least with $125 \mathrm{~kg} \mathrm{~N}$ $\mathrm{ha}^{-1}+60 \mathrm{~kg} \mathrm{SiO}_{2} \mathrm{ha}^{-1}$.

On the combined effect of variety and fertilizer (Fig. 3), the application of $125 \mathrm{~kg} \mathrm{~N} \mathrm{ha}^{-1}+60 \mathrm{~kg} \mathrm{SiO}_{2} \mathrm{ha}^{-1}$ to Peizataifeng showed the highest SPS activity and was significantly different from all other treatments. Lowest SPS activity was seen with the application of $100 \mathrm{~kg} \mathrm{~N}$ $\mathrm{ha}^{-1}$ to Peizataifeng, though it was insignificantly different from others. It was further shown that application of $100 \mathrm{~kg} \mathrm{~N} \mathrm{ha}^{-1}$ and 'no fertilizer application', insignificantly different from each other, gave the highest SPS activity in Peizataifeng at full-heading, while application of $125 \mathrm{~kg} \mathrm{~N} \mathrm{ha}^{-1}+60 \mathrm{~kg} \mathrm{SiO}_{2} \mathrm{ha}^{-1}$ produced the lowest SPS activity.

\section{Grain Quality in Super Rice}

On milling quality, brown rice yield was highest with nonfertilized Peizataifeng (85\%) and insignificantly different from obtained with the application of $100 \mathrm{~kg} \mathrm{~N} \mathrm{ha}^{-1}+60 \mathrm{~kg}$ $\mathrm{SiO}_{2} \mathrm{ha}^{-1}$ and $125 \mathrm{~kg} \mathrm{~N}^{-1}$ to Yuejinsimiao 2. On milled rice yield, all treatments were insignificantly different. However, Yuejinsimiao 2 fertilized with $125 \mathrm{~kg} \mathrm{ha}^{-1}$ $(73.05 \%)$ was highest in this attribute. Peizataifeng fertilized with $100 \mathrm{~kg} \mathrm{~N} \mathrm{ha}^{-1}+60 \mathrm{~kg} \mathrm{SiO}_{2} \mathrm{ha}^{-1}(66.33 \%)$ had the highest head rice recovery and was insignificantly different from Peizataifeng fertilized with $125 \mathrm{~kg} \mathrm{~N}^{-1}+60$ $\mathrm{kg} \mathrm{SiO}_{2}$ ha $^{-1}$ and Yuejinsimiao 2 fertilized with $100 \mathrm{~kg} \mathrm{~N}^{-1}$ and $125 \mathrm{~kg} \mathrm{~N} \mathrm{ha}^{-1}+60 \mathrm{~kg} \mathrm{SiO}_{2} \mathrm{ha}^{-1}$. It was further revealed that the 'no fertilizer application' treatments, $125 \mathrm{~kg} \mathrm{~N}^{-1}$ and $125 \mathrm{~kg} \mathrm{~N} \mathrm{ha}^{-1}+60 \mathrm{~kg} \mathrm{SiO}_{2} \mathrm{ha}^{-1}$ were the highest in brown and milled rice yield and head rice recovery, respectively, Also, both varieties were insignificantly different in brown rice yield and milled rice yield, but significantly different in head rice recovery; Yuejinsimiao 2 was higher than Peizataifeng.

Non-fertilized Peizataifeng (54.33\%) was highest on percentage of grains with chalkiness, and it further showed that Peizataifeng and 'no fertilizer applied' had higher percent grains with chalkiness for their respective categories.

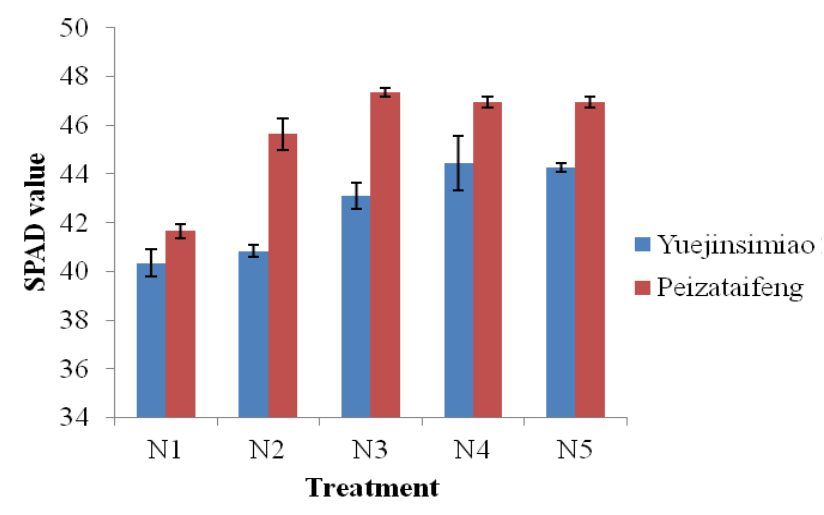

Fig. 1: Mean plant SPAD values for the interaction of super rice varieties and rice special fertilizer formulas at full-heading

$\mathrm{N} 1=$ no fertilizer applied; $\mathrm{N} 2=100 \mathrm{~kg} \mathrm{~N} \mathrm{ha}^{-1} ; \mathrm{N} 3=100 \mathrm{~kg} \mathrm{~N} \mathrm{ha}^{-1}+60 \mathrm{~kg}$ $\mathrm{SiO}_{2} \mathrm{ha}^{-1} ; \mathrm{N} 4=125 \mathrm{~kg} \mathrm{~N} \mathrm{ha}^{-1} ; \mathrm{N} 5=125 \mathrm{~kg} \mathrm{~N} \mathrm{ha}^{-1}+60 \mathrm{~kg} \mathrm{SiO}_{2} \mathrm{ha}^{-1}$

While non-fertilized Yuejinsimiao 2 had the highest chalky ratio of all treatments, and fertilization with $100 \mathrm{~kg} \mathrm{~N} \mathrm{ha}^{-1}+$ $60 \mathrm{~kg} \mathrm{SiO}{ }_{2} \mathrm{ha}^{-1}$ the highest in all fertilizer formulas, Yuejinsimiao 2 and Peizataifeng were insignificantly different.

Treatments were significantly different in polished grain protein; application of $125 \mathrm{~kg} \mathrm{~N} \mathrm{ha}^{-1}+60 \mathrm{~kg} \mathrm{SiO}_{2} \mathrm{ha}^{-1}$ to Yuejinsimiao 2 had the highest and Yuejinsimiao 2 and 'no fertilizer applied' were the more outstanding variety and fertilizer formula, respectively in this attribute. The fertilization of Peizataifeng with $125 \mathrm{~kg} \mathrm{~N} \mathrm{ha}^{-1}$ had the highest amylose content and was insignificantly different from non-fertilized Peizataifeng and fertilized with $100 \mathrm{~kg}$ $\mathrm{N} \mathrm{ha}^{-1}$. Also, Peizataifeng and $125 \mathrm{~kg} \mathrm{~N}^{-1}$ were highest in amylose content for variety and fertilizer, respectively. In all treatments amylose content was at least twice as much the protein content.

\section{Discussion}

In present study, plant height was significantly different between varieties at booting, full-heading and maturity likely due to varietal morphological or physiological factors connected with growth, especially internode elongation. 


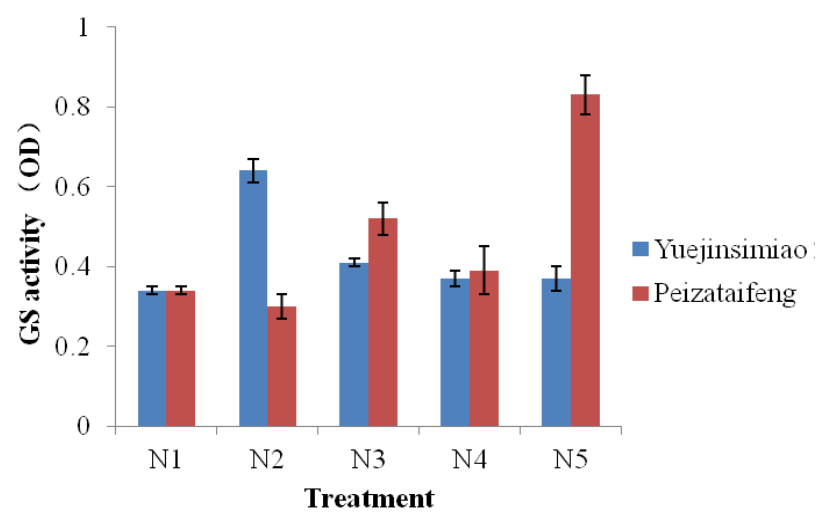

Fig. 2: Combined effect of varieties and rice special fertilizer formulas on GS activity at booting

$\mathrm{N} 1=$ no fertilizer applied; $\mathrm{N} 2=100 \mathrm{~kg} \mathrm{~N} \mathrm{ha}^{-1} ; \mathrm{N} 3=100 \mathrm{~kg} \mathrm{~N} \mathrm{ha}^{-1}+60 \mathrm{~kg}$ $\mathrm{SiO}_{2} \mathrm{ha}^{-1} ; \mathrm{N} 4=125 \mathrm{~kg} \mathrm{Nha}^{-1} ; \mathrm{N} 5=125 \mathrm{~kg} \mathrm{Nha}^{-1}+60 \mathrm{~kg} \mathrm{SiO}_{2} \mathrm{ha}^{-1}$

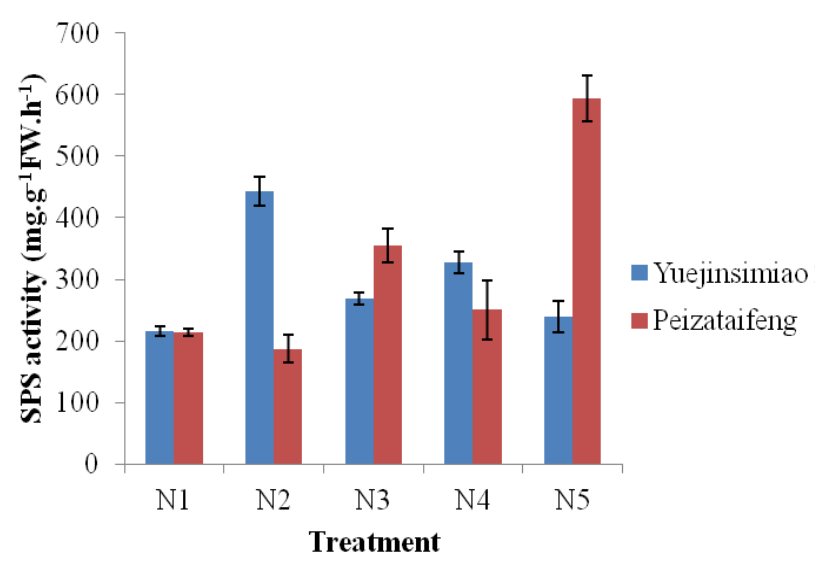

Fig. 3: Combined effect of varieties and rice special fertilizer formulas on SPS activity at booting

$\mathrm{N} 1=$ no fertilizer applied; $\mathrm{N} 2=100 \mathrm{~kg} \mathrm{~N} \mathrm{ha}^{-1} ; \mathrm{N} 3=100 \mathrm{~kg} \mathrm{~N} \mathrm{ha}^{-1}+60 \mathrm{~kg}$ $\mathrm{SiO}_{2} \mathrm{ha}^{-1} ; \mathrm{N} 4=125 \mathrm{~kg} \mathrm{Nha}^{-1} ; \mathrm{N} 5=125 \mathrm{~kg} \mathrm{~N} \mathrm{ha}^{-1}+60 \mathrm{~kg} \mathrm{SiO}_{2} \mathrm{ha}^{-1}$

Plant height is influenced by the lengths and total number of elongated internodes (Huang et al., 1996) and by environmental factors. In this study, rice special fertilizer was the major environmental factor to influence plant height. Probably at mid-tillering to booting, release of nutrients from fertilizer was greatest and/or roots had grown deep enough to absorb fertilizer better - to have accounted for the marked increase in plant height for all fertilized treatments, and the release of nutrients in this case may have been influenced by higher soil temperatures. Peizataifeng attaining higher heights may be its genotypic character.

Leaf area and LAI increases with increase in nitrogen level (Oscar and Tollennar, 2006) and is related with photosynthesis, and as a determinant of dry matter production and hence yield, has been widely accepted. LAI is dependent on factors like variety, planting density and fertilizers (Yoshida, 1972). In present study, though Yuejinsimiao 2 and Peizataifeng had insignificantly different LAI values at booting, full-heading and maturity, yet
Peizataifeng was slightly higher in LAI values at both fullheading and maturity. With fertilizers, $125 \mathrm{~kg} \mathrm{~N} \mathrm{ha}^{-1}$ produced the highest LAI at maturity, while for the interaction of variety and fertilizer, application of $125 \mathrm{~kg} \mathrm{~N}$ $\mathrm{ha}^{-1}$ to Peizataifeng gave the largest LAI at maturity. LAI increased sharply from mid-tillering to booting for all varieties, fertilizers and variety-fertilizer interactions, thus indicating high availability of nutrients (NPK), progressed to full-heading and then declined sharply at maturity. This sharp decline in LAI could be due to senescence of leaves after the reproductive phase.

Rice varieties with different characteristics have different optimum or threshold SPAD values under the same nitrogen inputs (Balasubramanian et al., 2000; Huang et al., 2008). The average SPAD value for the varieties Lalat and Swarna were found to be 35.4 and 40.1 , respectively for attaining optimum yield. This was estimated from the relationship between the average SPAD value from 15 days after transplanting to heading and rice grain yield of both the varieties. Huang et al. (2008) estimated different SPAD threshold values for two hybrid varieties using the same relationship for efficient nitrogen management. The SPAD threshold for optimizing nitrogen management was 35 for indica varieties grown under tropical condition (Peng et al., 1996). The two indica varieties used in this experiment had SPAD values above the threshold for optimizing $\mathrm{N}$ and this could have resulted in the higher grain filling, especially at lower SPAD values in non-fertilized treatments which gave lower yields. Silicon promotes $\mathrm{CO}_{2}$ assimilation in the leaf blades and translocation of assimilated products to the panicle (Takahashi et al., 1996). In present study, SPAD value showed a direct relationship with yield.

The photosynthetic rate of leaf blades was positively correlated with their nitrogen content (Allahyar, 2012). As much as existed variations in SPAD values amongst varieties, fertilizer formulas and treatments (variety $\mathrm{x}$ fertilizer) in this experiment, similar was expected of net photosynthetic rate. Differences in varietal response to $\mathrm{N}$ fertilizer epitomizes periods of high net photosynthetic rate. Whether silicon was involved in net photosynthesis at the reproductive stage could not be clearly ascertained as silicon was associated with lower net photosynthesis at full heading only for Peizataifeng and higher net photosynthesis of Yuejinsimiao 2 at 15 DAFH. Allahyar Fallah (2012) found that the photosynthesis rate was not affected by silicon addition but nitrogen increased net photosynthetic rate.

Grain development in rice depends on the establishment and maintenance of a photosynthetically active canopy, which acts as a major nitrogen store before internal $\mathrm{N}$ is translocated to the panicle. As this process occurs at the expense of the photosynthetic machinery, canopy longevity and maintenance of the photosynthetic capacity are vital for continuous remobilization of $\mathrm{N}$ and starch accumulation (Hawkesford and Howarth, 2010). $\mathrm{GS}_{1}$ plays a major role in the synthesis of glutamine in older leaves which is then transported to panicles 
(Masclaux et al., 2001), a process positively related to yield and N-use efficiency. In this experiment, GS activity in flag leaves at booting was significantly affected by variety and fertilizers. Where $\mathrm{N}$ with silicon was applied to Peizataifeng, activity of GS was high and so yields, and this correlates with the above given reference of Masclaux et al. (2001). However, the reverse was seen with Yuejinsimiao 2, and delayed GS activity was noticed to be related with lower yields.

Sucrose-phosphate synthase (SPS) is a key regulatory enzyme in the partitioning of photo-assimilates to either sucrose or starch in leaves (Huber et al., 1989). In this study, SPS activity in flag leaves was significantly affected by both variety and fertilizer. Peizataifeng, $125 \mathrm{~kg} \mathrm{~N} \mathrm{ha}^{-1}+60 \mathrm{~kg}$ $\mathrm{SiO}_{2} \mathrm{ha}^{-1}$ and Peizataifeng fertilized with $125 \mathrm{~kg} \mathrm{~N} \mathrm{ha}^{-1}+60$ $\mathrm{kg} \mathrm{SiO}_{2} \mathrm{ha}^{-1}$ had higher SPS activity at booting. At fullheading in Peizataifeng, highest SPS activity was detected in $100 \mathrm{~kg} \mathrm{~N} \mathrm{ha}^{-1}$. Where no silicon was added to fertilizers, plants had increased SPS activity, while addition of silicon was related with decreased SPS activity. Relatively, the rate of change in SPS activity for $125 \mathrm{~kg} \mathrm{~N} \mathrm{ha}^{-1}$ between booting and full-heading was small and this may have influenced its higher grain yield. The rate of change in SPS activity between booting and full heading in $100 \mathrm{~kg} \mathrm{~N} \mathrm{ha}^{-1}+60 \mathrm{~kg}$ $\mathrm{SiO}_{2} \mathrm{ha}^{-1}$ was second to $125 \mathrm{~kg} \mathrm{~N} \mathrm{ha}^{-1}$, and was likewise in grain yield. It may therefore be seen that a gradual change in SPS activity (SPS activity not moving too sharply away from an optimum activity level) between booting and heading could be vital for high yields.

In this experiment, $\mathrm{N}, \mathrm{P}, \mathrm{K}$ and $\mathrm{Si}$ concentrations varied amongst the five fertilizer formulas, and the effect on rice grain quality was investigated. Investigation of grain quality in present study revealed that brown rice yield was high with 'no fertilizer' and lower when silicon was applied. Bhattacharya (2011) advanced variety, degree of milling and breakage as three principal reasons for variation in milling yield of rice. As grains were subjected to equal degree of milling in present study, insignificant difference between treatments suggests that milled rice yield was neither affected by variety nor fertilizer. Though variety had an influence on head rice recovery, addition of silicon gave a more pronounced influence. Dilday (1988) in experiment on Lemont variety showed that nitrogen fertilizer has an influence on milling yield of rice. The percentage of broken kernels will approximately double when no nitrogen is applied as compared to proper nitrogen application at preflood or in split applications. In present study, the percentage of broken kernels in non-fertilized Peizataifeng, went close to doubling of Peizataifeng fertilized with $100 \mathrm{~kg}$ $\mathrm{N} \mathrm{ha}{ }^{-1}+60 \mathrm{~kg} \mathrm{SiO}_{2} \mathrm{ha}^{-1}$, thus supporting that $\mathrm{N}$ and $\mathrm{Si}$ fertilization both benefit head rice recovery.

The high chalkiness in the rice grain increases the possibility of breakage during milling and this reduces the quality of rice. Conversely, chalk-free rice has a lower tendency to break, and results in increased rice recovery, thereby boosting potential returns for farmers.
This assertion was also supported by Singh et al. (2003). Both genetic and environmental factors affect chalkiness of rice grains (Fitzgerald et al., 2008; Zhou et al., 2009). The high percent chalkiness of Peizataifeng and no fertilizer treatments grains must have influenced the emergent low head rice recovery. This may have been due to the fact, where no $\mathrm{N}$ fertilizer was applied grains not to have been well fortified with proteins that help to reduce breakage in milling. In support also, Yuejinsimiao 2 grains were least in protein content. However, where percent rice with chalkiness was high, chalky ratio was low, and the reverse also observed.

The impact of nitrogen fertilizer on grain quality has been widely studied and results showed that the protein content of grain increases with increase in nitrogen application rate (Miao and Chang, 1999; Cao et al., 2004). In this experiment it was evident especially in Yuejinsimiao 2. Hao et al. (2007) testified that nitrogen fertilizer could promote protein accumulation in the rice grain, and restrain amylose accumulation in grain and make gel consistency of brown rice higher. In this study, treatments were significantly different in their milled grain protein and amylose content, and high protein content was associated with low amylose content, adhering to the findings of Hao et al. (2007) above. Amount of applied N was somehow seen to correlate with protein accumulation, which was higher where silicon was added. Addition of silicon lowered amylose content.

\section{Conclusion}

Application of $125 \mathrm{~kg} \mathrm{~N}^{-1}$ gave the highest LAI at maturity, SPAD values and yield, especially with Peizataifeng, which were the taller plants and showed higher grain amylose, but with high percent chalkiness and lower protein content. Addition of silicon was related with decreased SPS activity, brown rice yield and amylose content, but increased grain protein. Milled rice yield was not affected by variety or fertilizer. Nitrogen reduced percent chalkiness of grains. Chalky ratio reduced with increase in chalkiness. We concluded that with deep application of rice special fertilizer Yuejinsimiao 2 had better grain quality, while Peizataifeng had better growth and photosynthesis characteristics, and quality of super hybrid rice were affected by both variety and fertilizer combinations.

\section{References}

Allahyar, F., 2012. Study of Silicon and Nitrogen Effects on some Physiological characters of Rice. Int. J. Agric. Crop Sci., 4: 238-241

Avigad, G. and P.M. Dey, 1996. Carbohydrate metabolism: Storage carbohydrates. In: Plant Biochemistry, pp: 143-204. P.M. Dey and J.B. Harborne (eds.). Academic Press, New York, USA

Balasubramanian, V., A.C. Morales, R.T. Cruz, T.M. Thiyagarajan, R. Nagarajan, M. Babu, S. Abdulrachman and L.H. Hai, 2000 Adaptation of the chlorophyll meter (SPAD) technology for realtime $\mathrm{N}$ management in rice: a review. Int. Rice Res. Inst., 5: 25-26 
Bhattacharya, K.R., 2011. Rice Quality: A Guide to Rice Properties and Analysis, pp: 26-115. Woodhead publishing Limited, Oxford, UK

Cao, C.F., L.C. Kong, J.L. Wang, B. Zhao and Z. Zhao, 2004. Effects of nitrogen nutrition on the quality of different types of wheat varieties. J. Triti. Crops, 24: 47-50

Castleden, C.K., N. Aoki, V.J. Gillespie, E.A. Macrae and W.P. Quick, 2004. Evolution and function of the sucrose-phosphate synthase gene families in wheat and other grasses. Plant Physiol., 135: 1753-176

Dilday, R.H., 1988. Effects of nitrogen fertilizer on milling and quality of rice (Oryza sativa). Proc. Arkansas Acad. Sci., 42: 26-27

Fageria, N.K., V.C. Baligar and C.A. Jones, 1997. Growth and Mineral Nutrition of Field Crops, pp: 229-235. Marcel Dekker Incorporation New York, USA

Fitzgerald, M.A., S.R. McCouch and R.D. Hall, 2008. Not just a grain of rice: the quest for quality. Trends Plant Sci., 14: 133-139

Fukumorita, T. and M. Chino, 1982. Sugar, amino acid and inorganic contents in rice phloem sap. Plant Cell Physiol., 23: 273-283

Gately, T.F., L. Quirke and S. Ormonde, 1988. Sources of Nitrogen for Spring Barley, pp: 14-15. Soils and Grassland Production research Report, Dublin. An foras Taluntais

Hao, H.L., Y.Z. Wei, X.E. Yang, Y. Feng and C.Y. Wu, 2007. Effects of different nitrogen fertilizer levels on $\mathrm{Fe}, \mathrm{Mn}, \mathrm{Cu}$ and $\mathrm{Zn}$ concentrations in shoot and grain quality in rice (Oryza sativa L.). Rice Sci., 14: 289-294

Hawkesford, M.J. and J.R. Howarth, 2010. Transcriptional profiling approaches for studying nitrogen use efficiency. Annu. Plant Rev., 42: 41-62

Huang, J., F. He, K. Cui, R.J. Buresh, B. Xu, W. Gong and S. Peng, 2008. Determination of Optimal Nitrogen Rate for Rice Varieties using a Chlorophyll Meter. Field Crops Res., 105: 70-80

Huang, N., B. Courtois and G.L. Wang, 1996. Association of quantitative trait loci for plant height with major dwarfing genes in rice. Heredity, 77: $130-137$

Huber, S.C., Nielsen T.H., Huber J.L. and D.M. Pharr, 1989. Variation among species in light activation of sucrose-phosphate synthase. Plant Cell Physiol., 30: 277-285

Ireland, R.J. and P.J. Lea, 1999. The Enzymes of Glutamine, Glutamate, Asparagine and Aspartate Metabolisms: in Singh BK, Plant Amino Acids: Biochemistry and Biotechnology, pp: 49-109. Marcel Dekker, New York, USA

Luo, X.W., E.H. Jiang, Z.M. Wang, X.R. Tang, J.H. Li and W.T. Chen, 2008. Precision rice hill-drop drilling machine. Trans. Chin. Soc. Agric. Eng., 24: 52-56

Luo, X.W., T. Liu, E.H. Jiang and Q. Li, 2007. Design and experiment of hill sowing wheel of precision rice direct-seeder. Trans. Chin. Soc. Agric. Eng., 23: 108-112

Luo, X.W., Z. Ou, E.H. Jiang, Z.W. Li and S.X. Huang, 2005. Experimental research on precision rice direct-seeder with hill sowing. Trans. Chin. Soc. Agric. Eng., 36: 37-40

Matloob, A., A. Khaliq, A. Tanveer and A. Wahid, 2015. Dry matter accumulation and growth response of zero tilled direct seeded fine rice to different weed competition durations and sowing times. Int. J. Agric. Biol., 17: 41-50
Miao, Y.F. and A.F. Chang, 1999. Effects of distribution proportion of N fertilizer on yield and colony of wheat. J. Triti. Crops, 19: 43-45

Milam, M.R. and R. Sheppard, 1988. Influence of a Water Cover Crop and Nitrogen Rate on Rice Performance in Annual Progress Report, Northeast Res, pp: 103-104. Station and Macon Ridge Research Station, Loussiana Agriculture Experimental Station, Baton Rouge, Louisiana, USA

Oscar, R.V. and M. Tollennar, 2006. Effect of genotype, nitrogen, plant density and row spacing on the area-per-leaf profile in maize. Agron. J., 98: 94-99

Patrick, R.M. and F.H. Hoskins, 1974. Protein and amino acid content of rice as affected by application of nitrogen fertilizer. Cereal Chem., 51: 84-95

Peng, S., F.V. Gracia, R.C. Laza., A.L. Sanico, R.M. Visperas and K.G. Cassman, 1996. Increased N-use efficiency using a chlorophyll meter on high yielding irrigated rice. Field Crops Res., 47: 243-252

Reddy, B.B., B.C. Gosh and M.M. Panda, 1982. Effects of Levels of Nitrogen on Growth, Yield and Nitrogen Uptake of Rice Varieties. Int. Rice Res. Newslett., 4: 1

Reddy, M.D., M.M. Panda, B.C. Gosh and B.B. Reddy, 1987. Effect of N fertilizer on grain yield and $\mathrm{N}$ uptake by rice varieties under deep water conditions (51-100 cm). The J. Agric. Sci., 110: 53-59

Rojas, W.C., A.R. Alvarado and N.C. Belmar, 1983. Nitrogen fertilization of rice, effect on some agronomic characteristics. Agric. Technica, 43: 353-357

Singh, K. and N. Sharma, 1987. Effect of nitrogen on rice in an alakaline soil. Int. Rice Res. Newslett., 12: 61

Singh, N., N.S. Sodhi, M. Kaur and S.K. Saxena, 2003. Physicochemical morphological, thermal, cooking and textural properties of chalky and translucent kernels. Food Chem., 82: 433-439

Taiz, L. and V. Zeiger, 1998. Plant Physiology, $2^{\text {nd }}$ edition. Sinauer Assoc., Sunderland, Massachusetts, USA

Takebe, M. and T. Yoneyama, 1989. Measurements of leaf color scores and its implications to nitrogen nutrition of rice plants. Jpn. Agric. Res. Q., 23: 86-93

Tang, X.R., X.W. Luo, G.X. Li, Z.M. Wang, T.X. Zheng, W.T. Chen and S. Shu, 2009. Yield formation characteristics of precision hill-drop drilling early rice. Trans. Chin. Soc. Agric. Eng., 25: 84-87

Turner, F.T. and M.F. Jund, 1994. Assessing the nitrogen requirement of rice crops with a chlorophyll meter. Aust. J. Exp. Agric., 34: 1001-1005

Uauy, C., A. Distelfeld, T. Fahima, A. Blechl and J. Dubcovsky, 2006. A NAC gene regulating senescence improves grain protein, zinc and iron content in wheat. Science, 314: 1298-1301

Wang, Z.M., X.W. Luo, X.R. Tang, G.H. Ma, G.Z. Zhang and S. Zeng, 2010. Precision rice hill-direct-seeding technology and machine based on the combination of agricultural machinery and agronomic technology. J. South Chin. Agric. Univ., 31:91-95

Zhou, L., L. Chen, L. Jiang, W. Zhang, L. Liu, X. Liu, Z. Zhao, S. Liu, L. Zhang, J. Wang and J. Wan, 2009. Fine mapping of the grain chalkiness QTLqPGWC-7 in rice (Oryza sativa L.). Theor. Appl. Genet., 118: 581-590

(Received 28 August 2015; Accepted 09 April 2016) 